\title{
Heterogeneous Catalysts for Biodiesel Synthesis from Karanja Oil by Transesterification Process
}

\author{
Satish A.Patil ${ }^{\dagger}$ and R. R. Arakerimath ${ }^{\#}$ \\ ${ }^{\dagger}$ Mechanical Engineering. DYPIET, Pune (MS) India \\ \#G H Raisoni College of Engineering and Management, Wagholi, Pune, India
}

Accepted 01 Sept 2016, Available online 02 Sept 2016, Vol.6, No.5 (Oct 2016)

\begin{abstract}
The heterogeneous catalysts are playing an important role and are perspective catalysts in future for biodiesel production. These heterogeneous catalysis features lower corrosiveness, environmental friendliness, easy catalyst recovery and high process integrity, all at levels superior to those of homogeneous catalysis. The heterogeneous basic catalyst includes oxides of Magnesium, Aluminum and Calcium etc. All sort of experiments were conducted by using the engine. The performance and emission results obtained were analyzed and discussed. The different blends of Karanja Biodiesel were compared with fossil fuel diesel. From observations it could be concluded that the blends of Karanja with diesel up to $20 \%$ by volume could replace diesel for running the diesel engine with less emissions without modifying the engine and without sacrificing the power output. This will thus help in controlling air pollution to a great extent.
\end{abstract}

Keywords: Biodiesel synthesis, Transesterification, Heterogeneous, catalyst.

\section{Introduction}

Diesel fuels are used in many areas and have importance for the economy of countries. Because of the energy and global warming crisis, development of renewable energies, for example, $\mathrm{H}_{2}$ energy, solar energy and biodiesel have been focused worldwide. Biodiesel is made entirely from vegetable sources; it does not contain any sulphur, aromatic hydrocarbons, metals or crude oil residues. Due to the properties like high degradability, no toxicity, low emission of carbon monoxide, particulate matter and unburned hydrocarbons, Biodiesel has gained international attention as a source of alternative fuel. Biodiesel can be used in conventional compression ignition engines, which need almost no modification. Experimentation is done with Karanja oil methyl ester and their blends. The performance and emission results obtained were analyzed and discussed.

\section{Karanja}

It is available in Western Ghats of India. The average life of Karanja tree is 80-100 years. It grows naturally; having very deep roots to reach water, and is one of the few crops well-suited to commercialization by India's large population of rural poor. The tree is hardy, reasonably drought resistant and tolerant to salinity.

*Corresponding author Satish A.Patil is a Research Scholar and Dr.R. R. Arakerimath B is working as Dean Academics
The Karanja tree is of medium size, reaching a height of 15-25 meters. The tree bears green pods which after some 10 months change to a tan color. The pods are flat to elliptic, $5-7 \mathrm{~cm}$ long and contain 1 or 2 kidney shaped brownish red kernels. The yield of kernels per tree is reported between 8 to $24 \mathrm{~kg}$. The oil content varies from $27 \%$ to $39 \%$ Comparison between Homogeneous and Heterogeneous Catalyst.

\begin{tabular}{|c|c|c|}
\hline & Homogeneous Catalyst & $\begin{array}{c}\text { Heterogeneous } \\
\text { Catalyst }\end{array}$ \\
\hline Phase & Liquid & Liquid, Gas, Solid \\
\hline Diffusivity & $\begin{array}{l}\text { High diffusivity. Having } \\
\text { all reactants and catalyst } \\
\text { in one phase enhances } \\
\text { dramatically the } \\
\text { diffusivity under proper } \\
\text { stirring. }\end{array}$ & $\begin{array}{c}\text { Diffusivity might be an } \\
\text { issue for catalysts with } \\
\text { low surface area. }\end{array}$ \\
\hline $\begin{array}{c}\text { Catalyst } \\
\text { Separation }\end{array}$ & $\begin{array}{l}\text { The separation of the } \\
\text { products from the } \\
\text { catalyst is generally } \\
\text { expensive, the only } \\
\text { exception being in } \\
\text { biphasic catalysis. }\end{array}$ & $\begin{array}{l}\text { The separation of the } \\
\text { products from the } \\
\text { catalyst is usually } \\
\text { straightforward. }\end{array}$ \\
\hline Recycling & $\begin{array}{l}\text { Recycling is expensive } \\
\text { due to difficult treatment } \\
\text { of the spent catalyst. }\end{array}$ & $\begin{array}{l}\text { Recycling is usually } \\
\text { straightforward, } \\
\text { although the catalyst } \\
\text { might need } \\
\text { reactivating treatment. }\end{array}$ \\
\hline $\begin{array}{c}\text { Heat } \\
\text { Transfer }\end{array}$ & $\begin{array}{c}\text { High Heat Transfer. } \\
\text { Having all reactants and } \\
\text { catalyst in one phase } \\
\text { enhances dramatically } \\
\text { the heat transfer under } \\
\text { proper stirring. }\end{array}$ & $\begin{array}{l}\text { Heat Transfer might be } \\
\text { an issue due to the } \\
\text { different heat } \\
\text { capacities of reactants } \\
\text { and catalyst. }\end{array}$ \\
\hline
\end{tabular}




\section{Advantages of Heterogeneous catalyst}

1) Excess methanol is removed by vaporization and recycled to the process with fresh methanol.

2) The catalyst is very stable with no metal leaching.

3) There is no formation of either glycerate salts or metal soaps.

4) No neutralization step is required,

5) No introduction of water. (No washing)

6) No salt formation.

7) These accounts for exceptional purity glycerol that is free of water and salt.

8) There is no waste production of low-value fatty acids.

9) This Process is economical.

\section{Research work}

The three different biodiesels were produced with the following three different feed stocks and heterogeneous catalyst separately. The properties of biodiesel and its blends have been checked and compared with diesel fuel are given below. The engine performance tests have been carried out for different compression ratios. The performance and emission results have been studied as follows.

\section{Karanja oil and $\mathrm{SiO}_{2}$ catalyst}

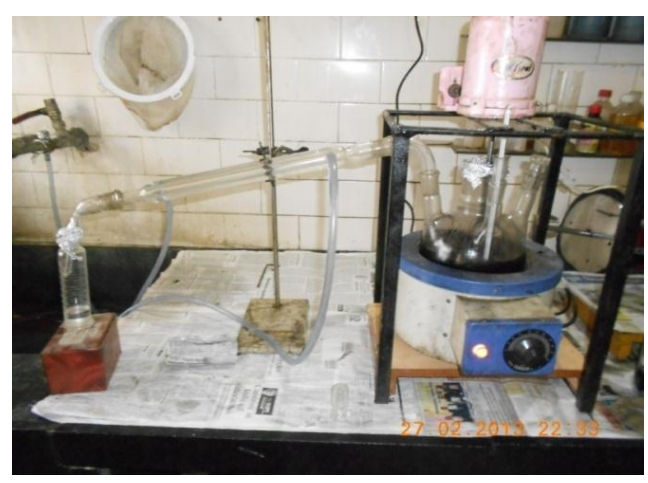

Fig.1 Transesterification setup

\section{Experimental setup and specifications}

Set up under test is Kirloskar TV1 VCR having 3.5 HP @ 1500 Rpm, One Cylinder, Four Stroke, Constant Speed, Water Cooled, Diesel Engine

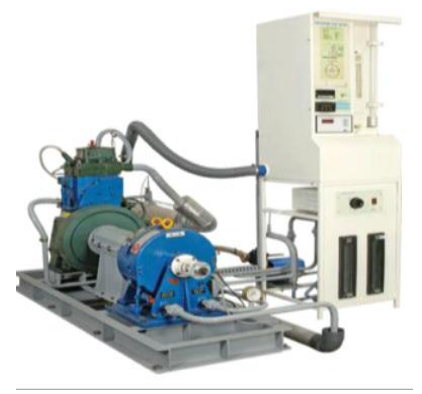

Fig.2 Engine set up

\section{Engine Specifications}

\begin{tabular}{|c|c|}
\hline Make & Kirloskar \\
\hline No. of Cylinders & 1 \\
\hline No. of Strokes & 4 \\
\hline Type of Cooling & Water Cooled \\
\hline Power Developing Capacity & $\begin{array}{c}3.5 \mathrm{~kW} @ 1500 \\
\text { rpm }\end{array}$ \\
\hline Compression Ratio Range & $12-18$ \\
\hline Stroke & $110 \mathrm{~mm}$ \\
\hline Bore & $87.5 \mathrm{~mm}$ \\
\hline Cylinder Volume & 661 \\
\hline
\end{tabular}

\subsection{Preparation of blends of biodiesel}

At present the amount of biodiesel available is less than that of diesel. The biodiesel blended with diesel by volume as B10 (10\% Karanja biodiesel \& 90\% diesel fuel), B20 (20\% Karanja biodiesel \& 80\% diesel fuel), B30 (30\% Karanja biodiesel \& 70\% diesel fuel), B40 (40\% Karanja biodiesel \& 60\% diesel fuel), B50 (50\% Karanja biodiesel \& 50\% diesel fuel), B100 (100\% Karanja biodiesel \& $00 \%$ diesel fuel).Then the samples were proceed for testing of properties.

\subsection{Karanja oil and $\mathrm{SiO}_{2}$ catalyst}

Biodiesel is produced from Karanja oil using heterogeneous $\mathrm{SiO}_{2}$ catalyst. Tested Physical Properties of the Diesel, Karanja Biodiesel and its Blends are as follows

\begin{tabular}{|c|c|c|c|c|c|c|c|c|c|c|}
\hline \multirow[t]{2}{*}{$\sum_{i}^{0}$} & \multirow[t]{2}{*}{ 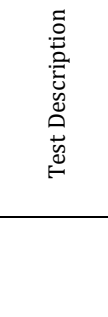 } & \multirow{2}{*}{ 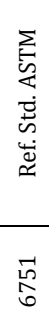 } & \multicolumn{2}{|c|}{ 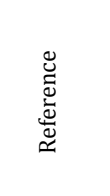 } & \multirow{2}{*}{ 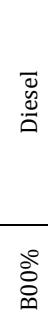 } & \multicolumn{4}{|c|}{ 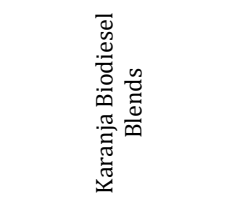 } & \multirow{2}{*}{ 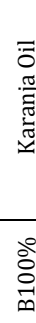 } \\
\hline & & & 节 & 节 & & 商 & 今े & 高 & 高 & \\
\hline 1 & Density & 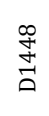 & $\frac{\breve{u}}{\Xi_{0}}$ & $\begin{array}{l}8 \\
\vdots \\
0 \\
\dot{1} \\
\infty \\
0 \\
0\end{array}$ & $\begin{array}{l}\stackrel{L}{0} \\
\infty \\
0 \\
0\end{array}$ & $\begin{array}{l}\infty \\
\infty \\
\infty \\
0 \\
0\end{array}$ & $\begin{array}{l}\mathscr{m} \\
\stackrel{2}{\infty} \\
0\end{array}$ & $\begin{array}{l}L \\
\infty \\
0\end{array}$ & $\begin{array}{l}\infty \\
\infty \\
\infty \\
\infty \\
0\end{array}$ & $\begin{array}{c}\stackrel{+}{\infty} \\
\infty \\
0\end{array}$ \\
\hline 2 & $\begin{array}{c}\text { Calorific } \\
\text { Value }\end{array}$ & $\begin{array}{l}\vec{h} \\
\hat{0}\end{array}$ & $\stackrel{\substack{\stackrel{\infty}{\Sigma} \\
\Sigma}}{\Sigma}$ & $\begin{array}{l}\stackrel{\varphi}{+} \\
\dot{m}\end{array}$ & 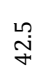 & $\underset{\sim}{\stackrel{H}{*}}$ & $\underset{\stackrel{H}{J}}{\stackrel{\sim}{H}}$ & $\stackrel{\widehat{N}}{\mathrm{j}}$ & $\begin{array}{l}\stackrel{n}{m} \\
\stackrel{+}{+}\end{array}$ & $\begin{array}{l}\infty \\
\infty \\
\stackrel{m}{m}\end{array}$ \\
\hline 3 & $\begin{array}{c}\text { Cetane } \\
\text { No. }\end{array}$ & $\stackrel{m}{a}$ & . & 点 & $\stackrel{\stackrel{2}{q}}{q}$ & $\stackrel{+}{\dot{q}}$ & $\begin{array}{l}\text { ָे } \\
\stackrel{+}{+}\end{array}$ & $\begin{array}{l}\stackrel{n}{n} \\
\stackrel{0}{\circ} \\
i n\end{array}$ & $\begin{array}{l}\text { in } \\
\text { in }\end{array}$ & ำ \\
\hline 4 & Viscosity & 导 & 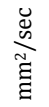 & 穵 & $\hat{\mathrm{N}}$ & ' & ' & ' & ' & लै \\
\hline 5 & Moisture & $\begin{array}{l}\stackrel{a}{人} \\
\stackrel{\text { N }}{ }\end{array}$ & do & $\begin{array}{l}\text { 广̊ } \\
\text { मे. } \\
\text { O. }\end{array}$ & $\mathbb{z}$ & $\mathbb{z}$ & $\mathbb{z}$ & $\mathbb{z}$ & $\overleftarrow{z}$ & \begin{tabular}{l} 
ț \\
\hdashline
\end{tabular} \\
\hline 6 & $\begin{array}{l}\text { Flash } \\
\text { Point }\end{array}$ & $\stackrel{\text { ̊ }}{ }$ &. & ' & పే & ' & ' & ' & ' & $\underset{\sim}{ \pm}$ \\
\hline 7 & $\begin{array}{l}\text { Fire } \\
\text { Point }\end{array}$ & $\stackrel{m}{\circ}$ & ৩ & ' & 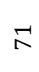 & ' & ' & ' & ' & in \\
\hline 8 & $\begin{array}{l}\text { Cloud } \\
\text { Point }\end{array}$ & $\begin{array}{l}\text { \& } \\
\stackrel{1}{N} \\
\text { ลิ }\end{array}$ & ט. & ' & i & ' & ' & ' & ' & $\wedge$ \\
\hline
\end{tabular}




\subsection{Performance Characteristics}

Experiments were conducted by using the engine. The performance and emission results obtained were analyzed and compared with fossil fuel diesel. The study of Karanja oil Biodiesel is discussed here in detail.

\section{Result Table Performance Characteristics}

\begin{tabular}{|c|c|c|c|c|c|c|}
\hline Blend & $\mathrm{CR}$ & Load & $\mathrm{BP}$ & BTHE & mech eff & sfc \\
\hline \multirow[t]{9}{*}{ B10 } & 16 & 3 & 0.89 & 11.08 & 11.49 & 0.77 \\
\hline & 16 & 6 & 1.73 & 16.66 & 30.19 & 0.51 \\
\hline & 16 & 9 & 2.6 & 19.7 & 31.71 & 0.44 \\
\hline & 17 & 3 & 0.89 & 12.16 & 12.47 & 0.7 \\
\hline & 17 & 6 & 1.76 & 16.73 & 22.26 & 0.51 \\
\hline & 17 & 9 & 2.65 & 20.17 & 31.14 & 0.43 \\
\hline & 18 & 3 & 0.89 & 10.32 & 14.97 & 0.83 \\
\hline & 18 & 6 & 1.72 & 15.33 & 25.37 & 0.56 \\
\hline & 18 & 9 & 2.59 & 18.91 & 35.67 & 0.45 \\
\hline \multirow[t]{9}{*}{$\mathrm{B} 20$} & 16 & 3 & 0.92 & 11.47 & 12.43 & 0.75 \\
\hline & 16 & 6 & 1.73 & 16.87 & 19.37 & 0.51 \\
\hline & 16 & 9 & 2.6 & 20.69 & 28.76 & 0.41 \\
\hline & 17 & 3 & 0.89 & 11.34 & 9.63 & 0.76 \\
\hline & 17 & 6 & 1.75 & 17.15 & 22.4 & 0.5 \\
\hline & 17 & 9 & 2.6 & 20.63 & 28.11 & 0.42 \\
\hline & 18 & 3 & 0.89 & 11.52 & 9.67 & 0.74 \\
\hline & 18 & 6 & 1.79 & 17.96 & 15.43 & 0.48 \\
\hline & 18 & 9 & 2.6 & 21.18 & 22.87 & 0.4 \\
\hline \multirow[t]{9}{*}{ B40 } & 16 & 3 & 0.95 & 11.56 & 8.82 & 0.74 \\
\hline & 16 & 6 & 1.78 & 19.47 & 13.13 & 0.44 \\
\hline & 16 & 9 & 2.61 & 19.54 & 20.6 & 0.44 \\
\hline & 17 & 3 & 0.94 & 11.68 & 8 & 0.73 \\
\hline & 17 & 6 & 1.78 & 17.38 & 13.28 & 0.49 \\
\hline & 17 & 9 & 2.61 & 19.59 & 19.42 & 0.44 \\
\hline & 18 & 3 & 0.89 & 11.36 & 6.94 & 0.75 \\
\hline & 18 & 6 & 1.79 & 17.58 & 14.76 & 0.49 \\
\hline & 18 & 9 & 2.6 & 20.7 & 22.66 & 0.41 \\
\hline \multirow[t]{9}{*}{$\mathrm{B} 60$} & 16 & 3 & 0.95 & 11.38 & 8.86 & 0.75 \\
\hline & 16 & 6 & 1.78 & 16.59 & 18.42 & 0.52 \\
\hline & 16 & 9 & 2.6 & 19.18 & 21.28 & 0.45 \\
\hline & 17 & 3 & 0.89 & 10.61 & 8.87 & 0.81 \\
\hline & 17 & 6 & 1.78 & 17.06 & 17.06 & 0.5 \\
\hline & 17 & 9 & 2.63 & 19.91 & 23.23 & 0.43 \\
\hline & 18 & 3 & 0.94 & 11.36 & 8.99 & 0.75 \\
\hline & 18 & 6 & 1.72 & 16.46 & 15.3 & 0.52 \\
\hline & 18 & 9 & 2.62 & 20.39 & 22.78 & 0.42 \\
\hline \multirow[t]{9}{*}{ D } & 16 & 3 & 0.93 & 9.92 & 16.61 & 0.86 \\
\hline & 16 & 6 & 1.75 & 18.01 & 27.34 & 0.57 \\
\hline & 16 & 9 & 2.62 & 18.67 & 36.78 & 0.46 \\
\hline & 17 & 3 & 0.93 & 10.92 & 14.9 & 0.79 \\
\hline & 17 & 6 & 1.8 & 16.82 & 24.33 & 0.51 \\
\hline & 17 & 9 & 2.61 & 20.27 & 32.33 & 0.42 \\
\hline & 18 & 3 & 0.93 & 11.24 & 14.88 & 0.76 \\
\hline & 18 & 6 & 1.79 & 17.1 & 24.24 & 0.5 \\
\hline & 18 & 9 & 2.58 & 20.43 & 33.66 & 0.42 \\
\hline
\end{tabular}

\subsection{Result Table of Emission Characteristics}

\begin{tabular}{|c|c|c|c|c|c|}
\hline Blends & CR & Load & $\mathrm{CO}$ & $\mathrm{HC}$ & $\mathrm{CO} 2$ \\
\hline \multirow[t]{9}{*}{ D } & 16 & 3 & 0.02 & 8 & 0.6 \\
\hline & 16 & 6 & 0.03 & 11 & 0.6 \\
\hline & 16 & 9 & 0.03 & 14 & 0.4 \\
\hline & 17 & 3 & 0.02 & 10 & 0.8 \\
\hline & 17 & 6 & 0.01 & 11 & 0.6 \\
\hline & 17 & 9 & 0.01 & 12 & 0.6 \\
\hline & 18 & 3 & 0.03 & 13 & 1 \\
\hline & 18 & 6 & 0.02 & 14 & 0.9 \\
\hline & 18 & 9 & 0.02 & 13 & 0.6 \\
\hline \multirow[t]{9}{*}{ B10 } & 16 & 3 & 0.02 & 16 & 0.7 \\
\hline & 16 & 6 & 0.02 & 17 & 0.6 \\
\hline & 16 & 9 & 0.01 & 17 & 0.5 \\
\hline & 17 & 3 & 0.02 & 9 & 0.7 \\
\hline & 17 & 6 & 0.01 & 14 & 0.8 \\
\hline & 17 & 9 & 0.01 & 15 & 0.5 \\
\hline & 18 & 3 & 0.02 & 10 & 0.8 \\
\hline & 18 & 6 & 0.01 & 12 & 0.7 \\
\hline & 18 & 9 & 0.01 & 15 & 0.6 \\
\hline \multirow[t]{9}{*}{ B20 } & 16 & 3 & 0.02 & 18 & 0.7 \\
\hline & 16 & 6 & 0.02 & 18 & 0.7 \\
\hline & 16 & 9 & 0.01 & 18 & 0.7 \\
\hline & 17 & 3 & 0.02 & 5 & 0.8 \\
\hline & 17 & 6 & 0.01 & 9 & 0.7 \\
\hline & 17 & 9 & 0.01 & 7 & 0.4 \\
\hline & 18 & 3 & 0.02 & 8 & 0.8 \\
\hline & 18 & 6 & 0.01 & 11 & 0.7 \\
\hline & 18 & 9 & 0.01 & 10 & 0.6 \\
\hline \multirow[t]{9}{*}{ B40 } & 16 & 3 & 0.01 & 11 & 0.8 \\
\hline & 16 & 6 & 0.01 & 13 & 0.7 \\
\hline & 16 & 9 & 0.01 & 14 & 0.5 \\
\hline & 17 & 3 & 0.02 & 11 & 0.8 \\
\hline & 17 & 6 & 0.01 & 12 & 0.8 \\
\hline & 17 & 9 & 0.01 & 13 & 0.6 \\
\hline & 18 & 3 & 0.02 & 12 & 0.9 \\
\hline & 18 & 6 & 0.01 & 7 & 0.7 \\
\hline & 18 & 9 & 0.01 & 9 & 0.6 \\
\hline \multirow[t]{9}{*}{ B60 } & 16 & 3 & 0.02 & 14 & 0.8 \\
\hline & 16 & 6 & 0.01 & 10 & 0.7 \\
\hline & 16 & 9 & 0.01 & 12 & 0.5 \\
\hline & 17 & 3 & 0.02 & 7 & 0.8 \\
\hline & 17 & 6 & 0.01 & 10 & 0.7 \\
\hline & 17 & 9 & 0.01 & 9 & 0.6 \\
\hline & 18 & 3 & 0.02 & 10 & 0.8 \\
\hline & 18 & 6 & 0.01 & 9 & 0.7 \\
\hline & 18 & 9 & 0.01 & 9 & 0.5 \\
\hline
\end{tabular}




\section{A) Performance Characteristics}

Brake Power

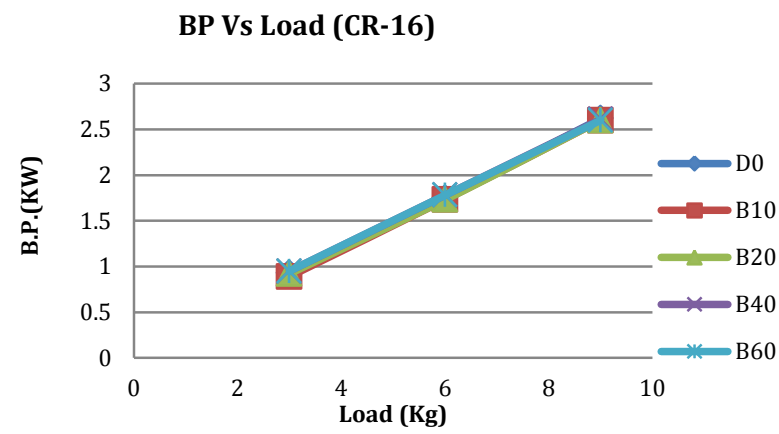

Fig.3 Variation of BP with load for Karanja biodiesel

The variation of brake thermal efficiency with brake power for diesel, Karanja biodiesel and their blends are shown in Fig 3 for CR-16, it is observed that brake power increase with load in all cases. Brake power is more or less equal with diesel at all loads for B10, B20, B40, B60 blends.

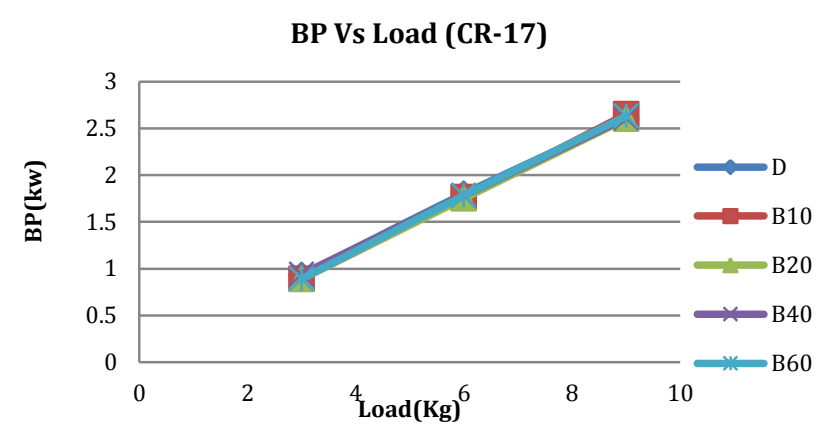

Fig.4 Variation of BP with load for Karanja biodiesel

The variation of brake thermal efficiency with brake power for diesel, Karanja biodiesel and their blends are shown in Fig. 4 for CR-17, it is observed that brake power increase with load in all cases. Brake power is more or less equal with diesel at all loads for B10, B20, B40, B60 blends.

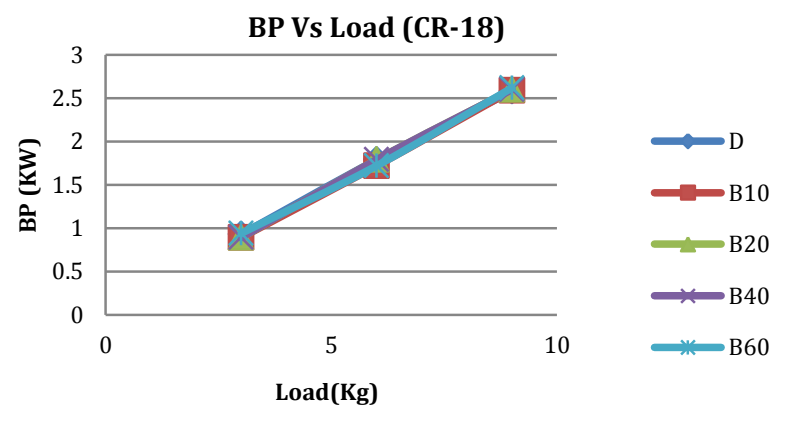

Fig.5 Variation of BP with load for Karanja biodiesel

The variation of brake thermal efficiency with brake power for diesel, Karanja biodiesel and their blends are shown in Fig. 5 for CR-18, it is observed that brake power increase with load in all cases. Brake power is more or less equal with diesel at all loads for B10, B20, B40, B60 blends.

Specific Fuel Consumption ( $s f$ )

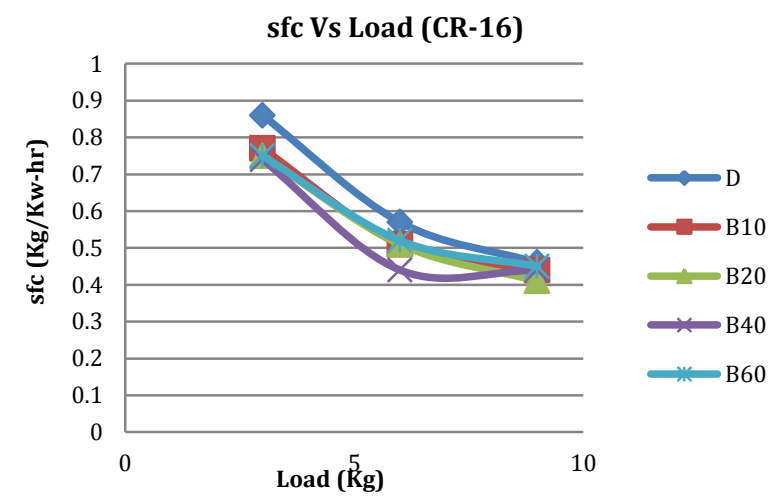

Fig. 6 Variation of BSFC with load for Karanja biodiesel

The variation of BSFC with load for Karanja biodiesel at CR 16 is given in fig.6. It is found that BSFC of diesel fuel is higher than other biodiesel blends at load $3 \mathrm{~kg}$ and $6 \mathrm{~kg}$ while it is near to same at $9 \mathrm{~kg}$ load. The BSFC for blends B10\% and B20\% shows its performance near to diesel fuel.

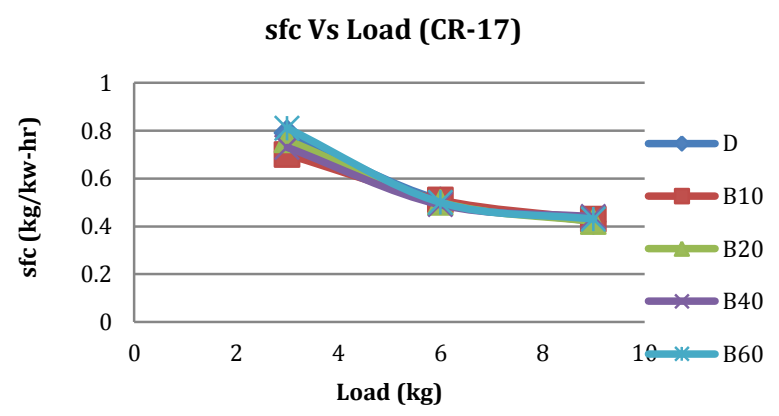

Fig. 7 Variation of BSFC with load for Karanja biodiesel

The variation of BSFC with load for Karanja biodiesel at CR 17 is given in fig.7. It is found that BSFC of diesel fuel is higher than other biodiesel blends at load $3 \mathrm{~kg}$ while it is near to same at $6 \mathrm{~kg}, 9 \mathrm{~kg}$ load.

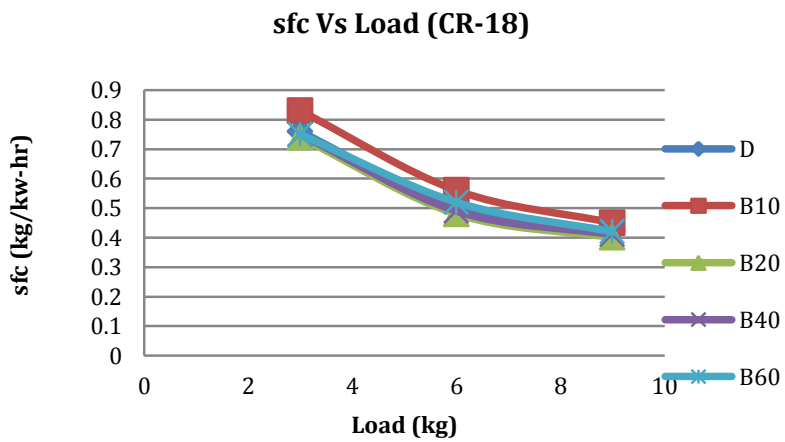

Fig.8 Variation of BSFC with load for Karanja biodiesel 
The variation of BSFC with load for Karanja biodiesel at CR 17 is given in fig.8. It is found that BSFC of diesel fuel is nearly equal to other biodiesel blends at all loads. The bsfc of B10 is higher than diesel at all loads.

\section{Brake Thermal Efficiency}

BTHE VS Load (CR-16)

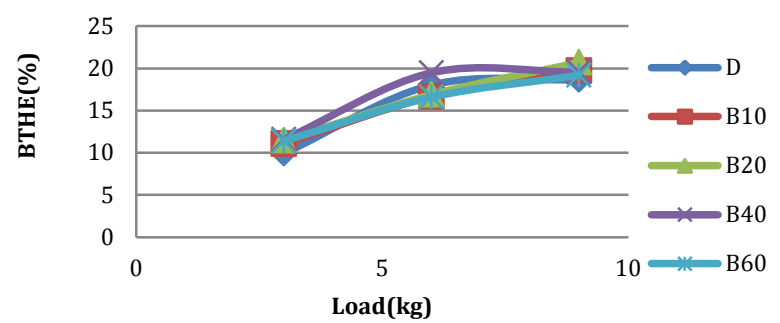

Fig.9 Variation of BTHE with load for Karanja biodiesel

The variation of brake thermal efficiency with load, for diesel and Karanja biodiesel blends is shown in fig.9. The Brake Thermal Efficiency for B20 and B40 at lower load is more or less equal to that of diesel. At higher load the Brake Thermal Efficiency increases for B20 and B40 blends.

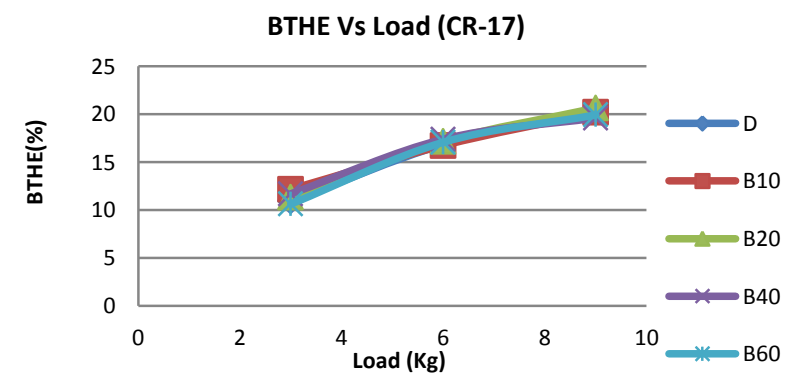

Fig.10 Variation of BTHE with load for Karanja biodiesel

The variation of brake thermal efficiency with load, for diesel and Karanja biodiesel blends is shown in fig. 10 . The Brake Thermal Efficiency for B20 and B40 at lower load is more or less equal to that of diesel. At higher load the Brake Thermal Efficiency increases for B20 and B40 blends.

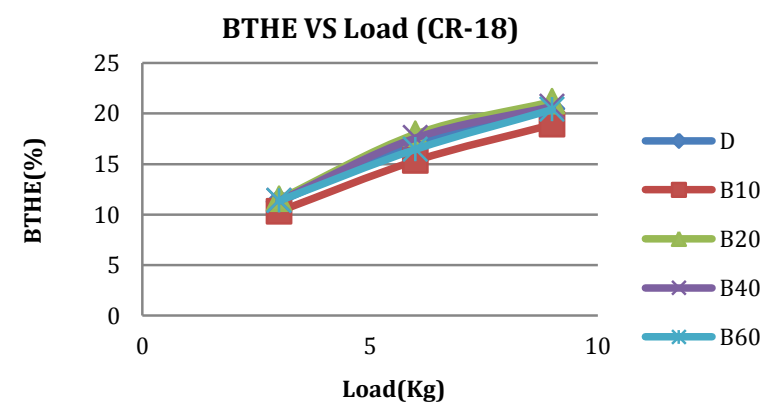

Fig.11 Variation of BTHE with load for Karanja biodiesel
The variation of brake thermal efficiency with load, for diesel and Karanja biodiesel blends is shown in fig.11. The Brake Thermal Efficiency for B20 and B40 at lower load is more or less equal to that of diesel. At higher load the Brake Thermal Efficiency increases for B20 and B40 blends

Mechanical Efficiency

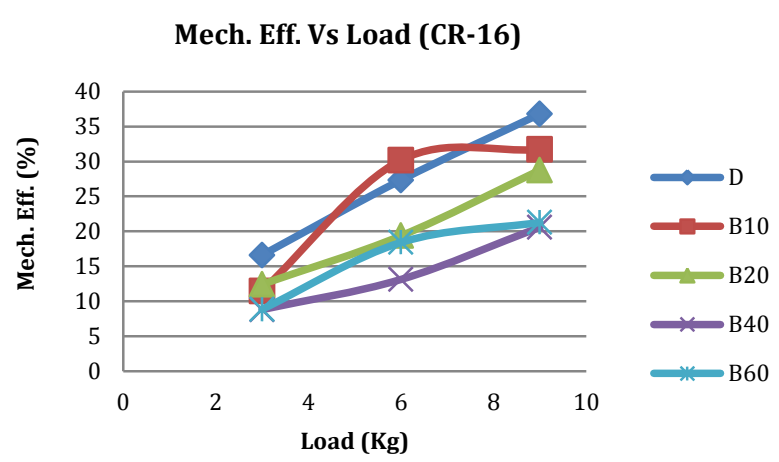

Fig.12 Variation of Mech. Eff. with load for Karanja biodiesel

The variation of mechanical efficiency with brake power, for diesel and Karanja blends is shown in fig. 12 . The mechanical efficiency of diesel is slightly higher than the Karanja biodiesel. Mechanical efficiency of $10 \%$ blend is very close to diesel, followed by $20 \%$ blend for entire range of operation. Maximum mechanical efficiency of $10 \%$ and $20 \%$ blend is $31.71 \%$ and $28.76 \%$ against, $36.78 \%$ of diesel oil. From the graph it is evident that with increase in concentration of Karanja biodiesel in neat diesel oil decreases the mechanical efficiency. This may be due to better lubricating property of the diesel which reduces frictional losses.

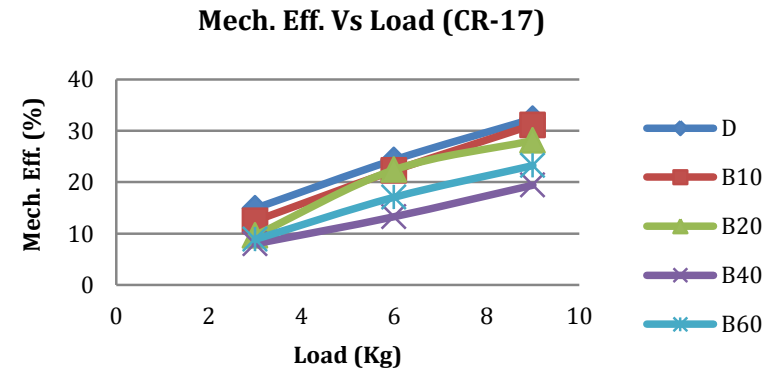

Fig.13 Variation of Mech. Eff. with load for Karanja biodiesel

The variation of mechanical efficiency with brake power, for diesel and Karanja blends is shown in fig.13. The mechanical efficiency of diesel is slightly higher than the Karanja biodiesel. Mechanical efficiency of $10 \%$ blend is very close to diesel, followed by $20 \%$ blend for entire range of operation. Maximum mechanical efficiency of $10 \%$ and $20 \%$ blend is $31.71 \%$ and $28.76 \%$ against, $36.78 \%$ of diesel oil. 


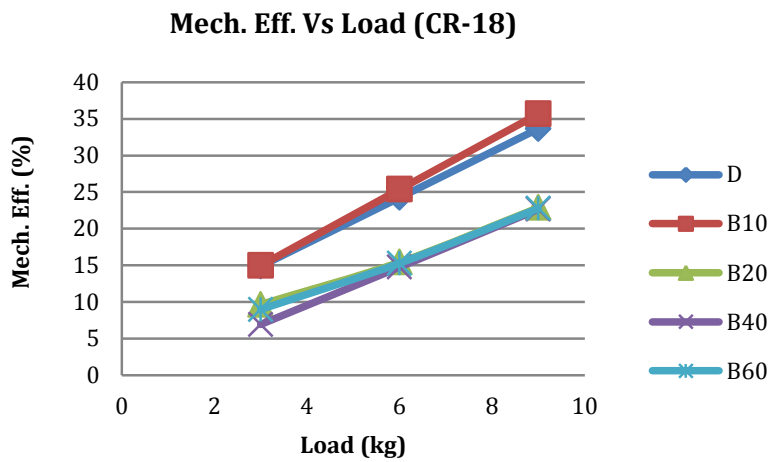

Fig.14Variation of Mech. Eff. with load for Karanja biodiesel

The variation of mechanical efficiency with brake power, for diesel and Karanja blends is shown in fig.14. The mechanical efficiency of diesel is slightly higher than the Karanja biodiesel. Mechanical efficiency of $10 \%$ blend is very close to diesel for entire range of operation. Maximum mechanical efficiency of $10 \%$ blend is $35.67 \%$ and $33.66 \%$ of diesel oil.

\section{B) Emission Characteristics}

\section{Carbon monoxide}

\section{CO Vs Load (CR-16)}

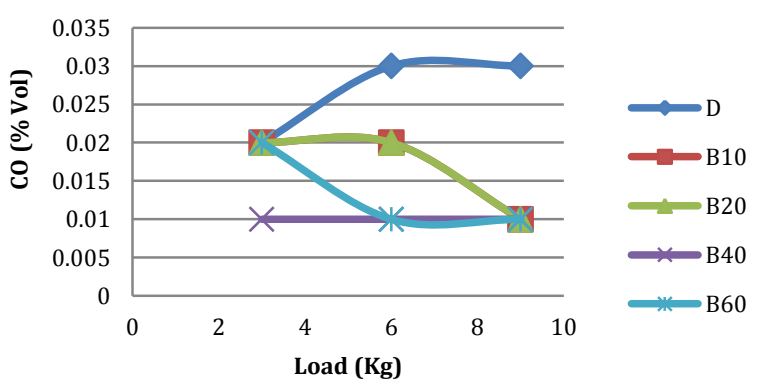

Fig. 15 Variation of CO with load for Karanja biodiesel

Fig.15 shows the variation of carbon monoxide emission with load for Karanja biodiesel and its blends in the test engine.The CO emission depends upon the strength of the mixture, availability of oxygen and viscosity of fuel. CO emission of all blends is lower than that of diesel. Among the blends $40 \%$ blend has a lower CO emission followed by $60 \%$ blend. CO emission of $10 \%$ and $20 \%$ blends is same and lower at maximum load about $0.01 \%$. CO emission of pure diesel is higher than all other blends for entire operating range and maximum of $0.03 \%$ occurs at the rated load. This due to incomplete combustion at higher loads which results in higher $\mathrm{CO}$ emissions.

Fig.16 shows the variation of carbon monoxide emission with load for Karanja biodiesel oil and its blends in the test engine for CR-17.The emission of $\mathrm{CO}$ is decreases with increase of loads for pure diesel and all biodiesel blends. The value of $\mathrm{CO}$ emission is minimum at full load about $0.01 \%$ by Vol. and maximum at lower load about $0.02 \%$ by Vol.

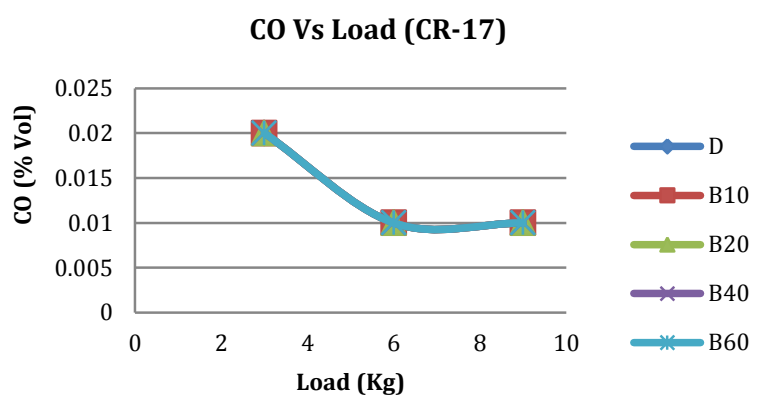

Fig. 16 Variation of CO with load for Karanja biodiesel

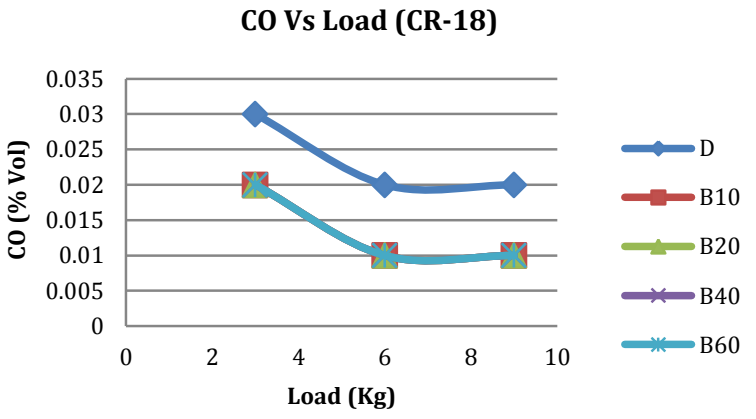

Fig.17 Variation of CO with load for Karanja biodiesel

Fig.17 shows the variation of carbon monoxide emission with load for Karanja biodiesel oil and its blends in the test engine at CR-18.CO emission of all blends of biodiesel and pure diesel decreases with increase of loadCO emission of pure diesel is higher than all other blends for entireoperating range and maximum of $0.03 \%$ of vol. occurs at minimum load and minimum of $0.02 \%$ of vol. at maximum load. CO emissions of all blends are maximum of $0.02 \%$ of vol. at lower load value and minimum of $0.01 \%$ vol. at the rated load.

\section{Unburned Hydro Carbon}

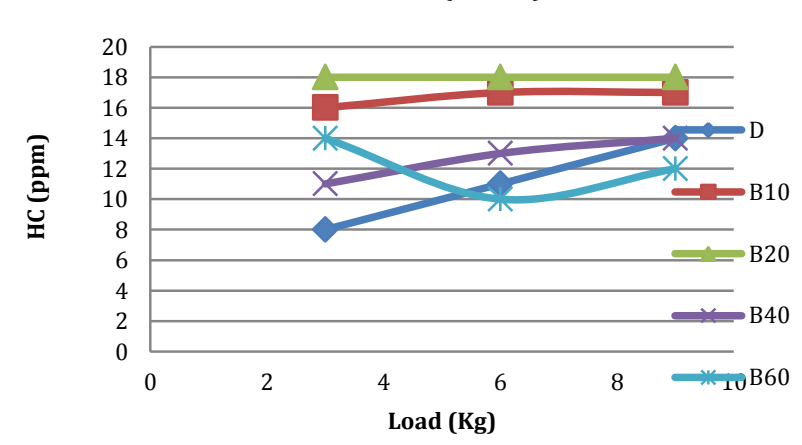

Fig.18 Variation of HC with load for Karanja biodiesel

Fig 18 shows the variation of emission of hydrocarbon with load for different blends of Karanja biodiesel and 
pure diesel. The emission of $\mathrm{HC}$ isincreasing with increase of loads. UHC of pure diesel has lower emission compared with all other biodiesel blends followed by $40 \%$ blend.The value of UHC of pure diesel and blend $40 \%$ is maximum about $14 \mathrm{ppm}$ and $16 \mathrm{ppm}$ respectively. The minimum value of UHC for both pure diesel and $40 \%$ is 8 ppm and 11 ppm respectively.

\section{HC Vs Load (CR-17)}

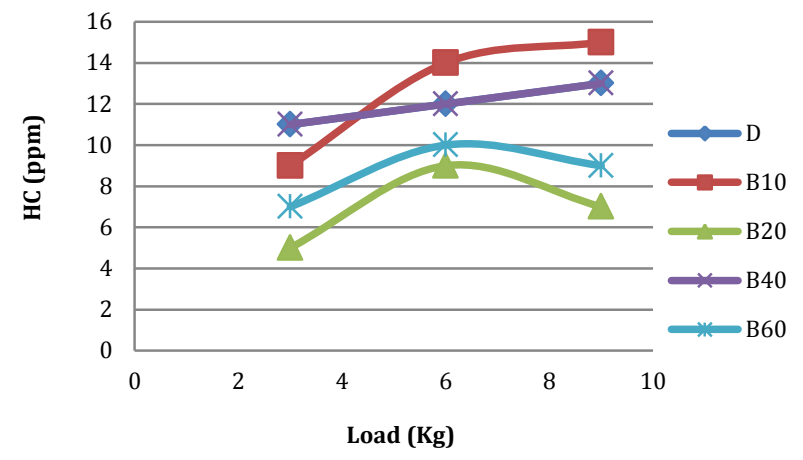

Fig.19 Variation of HC with load for Karanja biodiesel

Fig 19 shows the variation of emission of hydrocarbon with load for different blends of Karanja biodiesel and pure diesel. The emission of HC is increasing with increase of loads. UHC of pure diesel and $10 \%$ biodiesel blend have approximately similar performance characteristic. The $20 \%$ blend has lower emissions compared with all other biodiesel blends followed by $60 \%$ blend. $20 \%$ blend has lower UHC emission about, $5 \mathrm{ppm}$ at minimum load and $7 \mathrm{ppm}$ at maximum load.

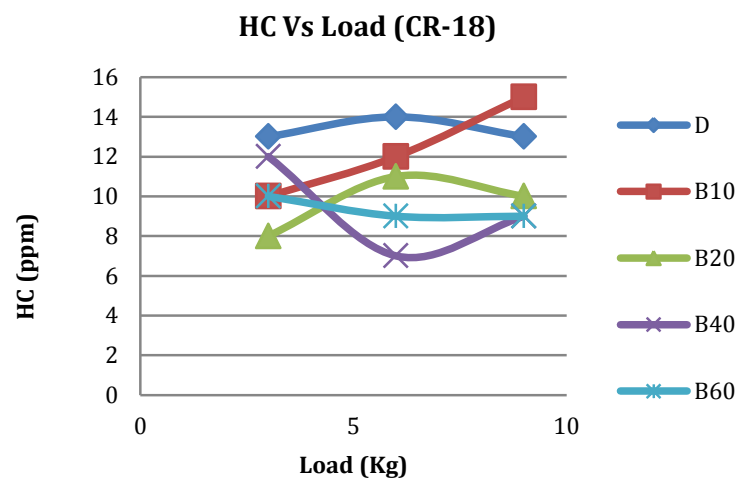

Fig.20 Variation of HC with load for Karanja biodiesel

Fig 20 shows the variation of emission of hydrocarbon with load for different blends of Karanja biodiesel and pure diesel at CR-18. The emission of HC is increasing with increase of loads. UHC of pure diesel has lower emission compared with all other biodiesel blends followed by $10 \%$ blend. The value of UHC of pure diesel and blend $10 \%$ is maximum about $13 \mathrm{ppm}$ and $15 \mathrm{ppm}$ at higher respectively loading condition. The minimum value of UHC for both pure diesel and 10\% is $13 \mathrm{ppm}$ and $10 \mathrm{ppm}$ respectively at lower loading condition. As blending of biodiesel increases in pure diesel UHC emission decreases.
Carbon Dioxide $\left(\mathrm{CO}_{2}\right)$

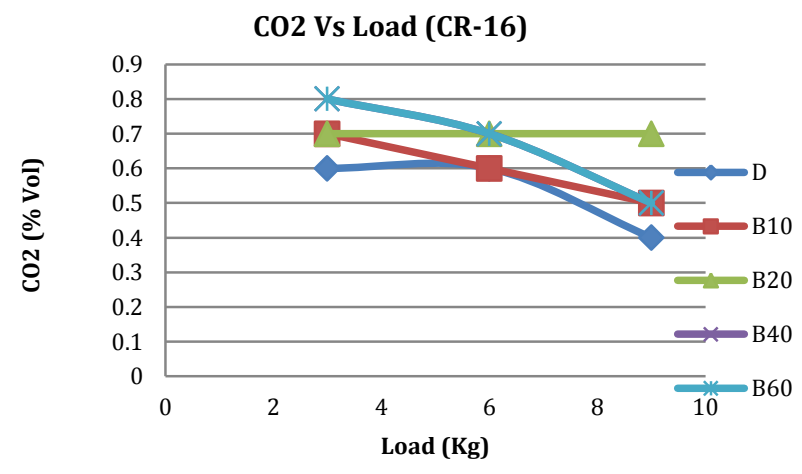

Fig.21 Variation of $\mathrm{CO}_{2}$ with load for Karanja biodiesel

Fig.21 shows the variation of carbon dioxide emission with load for Karanja biodiesel oil and its blends in the test engine.CO2 emissions for pure diesel and all biodiesel blends decreases with increase in load. Among all the blends $10 \%$ blend has a lower $\mathrm{CO} 2$ emission followed by $20 \%$ blend. CO2 emission of $60 \%$ blend is higher than all other blends for entire operating range and maximum at minimum load and minimum occurs at the rated load about $0.5 \%$. $\mathrm{CO} 2$ emission of pure diesel is lower than all other blends for entire operating range and minimum of $0.4 \%$ occurs at the rated load.

\section{C02 Vs Load (CR-17)}

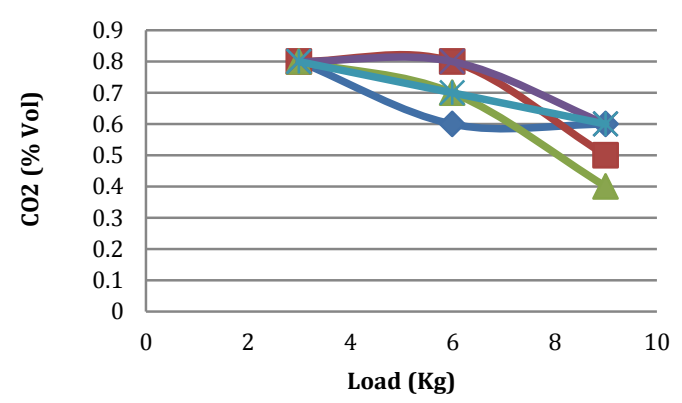

Fig.22 Variation of CO2 with load for Karanja biodiesel

Fig.22 shows the variation of carbon dioxide emission with load for Karanja biodiesel oil and its blends in the test engine for CR-17.CO2 emissions for pure diesel and all biodiesel blends decreases with increase in load. Among all the blends $10 \%$ blend has a lower $\mathrm{CO} 2$ emission followed by $20 \%$ blend. CO2 emission of $40 \%$ blend is higher than all other blends for entire operating range and maximum at minimum load and minimum occurs at the rated load about $0.6 \%$. $\mathrm{CO} 2$ emission of pure diesel is lower than all other blends for entire operating range and minimum of $0.6 \%$ occurs at the rated load.

Fig.23 shows the variation of carbon dioxide emission with load for Karanja biodiesel oil and its blends in the test engine at CR-18.CO2 emissions for pure diesel and all biodiesel blends decreases with increase in load. 


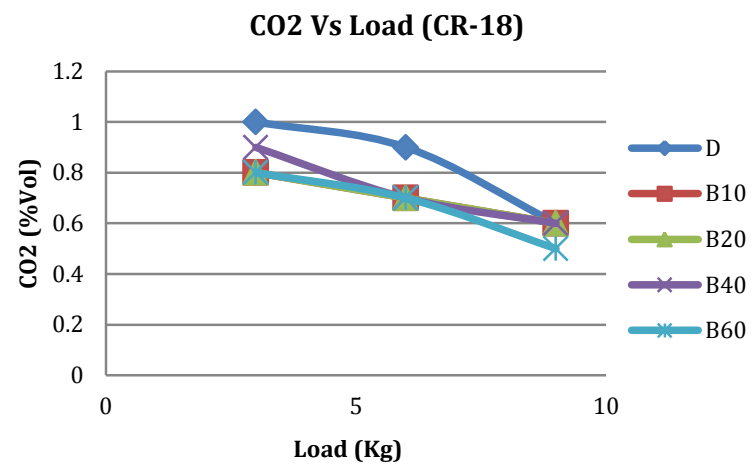

Fig.23 Variation of $\mathrm{CO}_{2}$ with load for Karanja biodiesel

Pure diesel has higher $\mathrm{CO} 2$ emissions than biodiesel blends of maximum $1 \%$ vol. at lower load and minimum of $0.6 \%$ vol. at higher load. Among all the blends $60 \%$ blend has a lower $\mathrm{CO} 2$ emission followed by $20 \%, 30 \%, 40 \%$ blends of maximum $0.9 \%$ vol. at lower load and minimum of $0.6 \%$ vol. at higher load. At higher loading condition $\mathrm{CO} 2$ emissions of blends and pure diesel are same and minimum.

\section{Conclusion}

There is a growing interest in the development of heterogeneous catalyst. The emphasis laid on the application of heterogeneous catalyst is mainly to overcome the limitation incurred by homogeneous one. Increasing biodiesel consumption requires optimized production processes that are compatible with high production capacities and that feature simplified operations, high yields, and the absence of special chemical requirements and waste streams. In the heterogeneous process, the catalyst is very stable with no metal leaching. There is no formation of either glycerate salts or metal soaps which affords the following advantages: no neutralization step is required, there is no introduction of water and there is no salt formation; these accounts for exceptional glycerol purity. In addition, there is no waste production of low-value fatty Acids. A heterogeneous catalyzed continuous process gives these objectives to be attained. A simple method was found to recover the basic sites to regenerate the catalyst that performed good activity and reproducibility.

The effects of Karanja biodiesel fuel on performance, emission of VCR diesel engine have been investigated and compared with base line diesel fuel.

The main observations are as follows:

1) Brake power is nearly equal to diesel fuel at all loads for all blends of biodiesel.

2) BSFC is nearly equal to diesel fuel at higher load.

3) Brake thermal efficiency at higher compression for biodiesel and it's blends decreases due to lower heating value of biodiesel and its injection of higher quantities compared to diesel for the same load conditions.
4) Mechanical efficiency decreases for biodiesel and its blends as compared to diesel, as percentage of biodiesel increase in pure diesel.

5) The emission of $\mathrm{CO}$ decreases as percentage of biodiesel increases; this is due to oxygen present in biodiesel which converts $\mathrm{CO}$ in $\mathrm{CO} 2$.

6) At full load condition HC emissions obtained is higher for B10 while for other blends HC emissions are equal to or less than diesel this is due to complete combustion of fuel at higher compression ratio.

7) At lower compression ratio emission of $\mathrm{CO} 2$ is higher for biodiesel blends this is due to oxygen present in biodiesel which convert $\mathrm{CO}$ into $\mathrm{CO} 2$.

8) From all these observations it could be concluded that the blends of Karanja with diesel up to $20 \%$ by volume could replace diesel for running the diesel engine with less emissions without modifying the engine and without sacrificing the power output. This will thus help in controlling air pollution to a great extent.

\section{References}

Dae-Won Lee, Young-Moo Park, Kwan- Young Lee (April 2009); Heterogeneous Base Catalysts For Transesterification in Biodiesel Synthesis. DOI 10.1007/s 10563-009-9068-6, 28.

Baste S. V. ,Bhosale A. V. and Chavan S. B. (26 July 2013) Emission Characteristics of Pongamia (Karanja) Biodiesel and Its Blending up to $100 \%$ in a CI Engine.;ISSN 2320 6063 Res. J. Agriculture and Forestry Sci.

Kale S. V. (March 2014); Emission Characteristics of DI-CI Engine Using Pongamia Biodiesel- Diesel Blen and Fuel. EISSN2249-8974.

Olatunji O. M., Ayotamuno M. J. (7 July 2014); Simulation of A CSTR Model For ThevetiaPeruviana Oil Transesterification In The Production of Biodiesel. Volume 5, Issue 7,ISSN 0976-6480.

Swapna G. K., Dr. M. C Math (June 2014); Experimental Studies on Performance and Exhaust Emission of a Direct Injection (DI) Diesel Engine By Using Mixtures of Jatropha And PongamiaPinnatta Methyl Ester and Its Diesel Blends. 6 ,ISSN: 2321-0869, Volume-2, Issue-6

K.NanthaGopal, R. ThundilKarupparaj (1 October 2014); Effect of Pongamia Biodiesel on Emission and Combustion Characteristics of DI Compression Ignition Engine. Ain Shams Engineering Journal (2014).

Kento T. Magara-Gomez, Michael R. Olson, TomoakiOkuda A. Walz\& James J (23 April 2012),'Sensitivity of Diesel Particulate Emission and Combustion to Blends of Petroleum Diesel and Biodiesel Fuel.; Schauer,Informa Ltd Registered in England and Wales Registered No.:1072954.

Panigrahi N., Mohanty M.K., Pradhan A.K. (NovemberDecember 2012) (IJERA)ISSN Non-Edible Karanja Biodiesel- A Sustainable Fuel for C.I. Engine' : 2248-9622 www.ijera.com Vol. 2, Issue 6.

Sharma Yogesh C., Singh Bhaskar; John Korstad (23 October 2010) Latest developments on application of heterogenous basic catalysts for an efficient and eco friendly synthesis of biodiesel: A review.

Chavan Mallesh, Amarnath H. K.,O. D. Hebbal (August 2014)Experimental Investigation on Performance, Emission and Combustion Characteristics of Single Cylinder Diesel Engine Running on Desert Date 
(BalanitesAegyptiaca) Biodiesel;International Journal of Engineering Research \& Technology (IJERT) Vol. 3 Issue 8, IJERT ISSN: 2278-0181.

Patil SatishA., Dr.R R Arakerimath (2014) Heterogeneous Catalysts for Economic Synthesis of Biodiesel by Transesterification: A review , International conference.

Feng Guo,Ning-Ning Wei, Zhi-Long Xiu , Zhen Fang ((2012)) Transesterification mechanism of soybean oil to biodiesel catalyzed by calcined sodium silicate. Fuel 93, 468-472

N. Viriya-empikul, P. Krasae , W. Nualpaeng, B. Yoosuk, K. Faungnawaki (2012)Biodiesel production over Ca-based solid catalysts derived from industrial wastes Fuel 92 ,239-244

Hamed Mootabadi, Babak Salamatinia, Subhash Bhatia, Ahmad Zuhairi Abdullah (2010),Ultrasonic-assisted biodiesel production process from palm oil using alkaline earth metal oxides as the heterogeneous catalysts Fuel 89,1818-1825

Hong-yanZeng, Zhen Feng, Xin Deng, Yu-qin Li (2008) Activation of $\mathrm{Mg}-\mathrm{Al}$ hydrotalcite catalysts for transesterification of rape oil. Fuel 87,3071-3076

ErtanAlptekin, Mustafa CanakciOptimization of transesterification for methyl ester production from chicken fat , Fuel 90 (2011) 2630-2638

Rubi Romero, Sandra Luz Martínez and Reyna NatividadBiodiesel Production by Using Heterogeneous Catalysts.

Sirichai Chantara-arpornchai (2012), Biodiesel Production from Palm Oil using Heterogeneous Base catalyst, International Journal of Chemical and Biological Engineering 6

Alexandre C. Dimian, Interrelation of Chemistry and Process Design in Biodiesel Manufacturing by Heterogeneous Catalysis, Top Catal (2010) 53:1197-1201

R.K. Mandloiet. al. / International Journal of Engineering Science and Technology Vol.2(10), 2010, 5902-5906The Effect of Bio-Fuel Blends and Engine Load on Diesel Engine Smoke Density for Sustainable Environment

Nanthagopal K., ThundilKaruppa Raj R. and Vijayakumar T. Journal of Petroleum Technology and Alternative Fuels Vol. 3(4), pp. 36-41, April 2012, Performance and emission characteristics of karanja methyl esters: Diesel blends in a direct injection compression-ignition (CI) engine
S.Antony Raja, D.S.Robinson smart, and C.Lindon Robert Lee. (April 2011) Biodiesel production from jatropha oil and its characterization. Research Journal of Chemical Sciences Vol. 1 (1)

Kazi Mostafijur Rahman, Mohammad Mashud, Md. Roknuzzaman and Asadullah Al Galib. Biodiesel from Jatropha Oil as an Alternative Fuel for Diesel Engine. International Journal of Mechanical \& Mechatronics Engineering IJMME-IJENS Vol:10 No:03

V.R. Sivakumar et. al. (2010) Statistical Analysis On The Performance Of Engine With Jatropha Oil As An Alternate Fuel . International Journal of Engineering Science and Technology Vol. 2(12), 7740-7757.

S.Hawash, G.ElDiwani, E.Abdel Kader (June 2011) Optimization of Biodiesel Production from Jatropha Oil By Heterogeneous Base Catalysed Transesterification. JEST Vol. 3 No. 6

Ittipon Worapun, Kulachate Pianthong and Prachasant Thaiyasuit (September 2010), Synthesis of biodiesel by two-step transesterification from crude jatrophacurcus L.oil using ultrasonic irradiation assisted KKU Engineering Journal Vol.37 No.3 (169-179) July 3

Fei-ling Pua, Zhen Fang, SaraniZakaria, FengGuo and Chinhua Chia, Direct production of biodiesel from high-acid value Jatropha oil with solid acid catalyst derived from lignin. Pua et al. Biotechnology for Biofuels 2011, 4:56

Gerard Hillion, Bruno Delfort , Dominique le Pennec, Laurent Bournay, Jean-Alain Chodorge (2003) Biodiesel Production by continuous process using Heterogeneous catalyst. Prepr. Pap.-Am. Chem. Soc., Div. Fuel Chem., 48(2), 636

V.R. Sivakumaret. al. / International Journal of Engineering Science and TechnologyVol. 2(12), 2010, 7740-7757 Statistical Analysis on the performance of Engine with Jatropha oil as an alternate fuel

RaoY. V. Hanumantha et al. J. of the Braz. Soc. of Mech. Sci. \& Eng. Use of Jatropha Oil Methyl Ester and Its Blends as an Alternative Fuel in Diesel Engine

Res.J.Chem.Sci Mohamed F. Al-Dawody et al. (June 2011)International Journal of Engineering Science and Technology (IJEST) Vol. 3 No. 6, Effect Of Soybean Oil Biofuel Blending On ThePerformance And Emissions of Diesel Engine Using Diesel-Rk Software

Bulk Agro (India) Pvt. Ltd. (http://www. bulkagro. com) 